\title{
НОВЫЕ ДАННЫЕ ОБ ОСОБЕННОСТЯХ ГЕОЛОГИЧЕСКОГО СТРОЕНИЯ И ПЕРСПЕКТИВАХ НЕФТЕГАЗОНОСНОСТИ ПАЛЕОЗОЙСКИХ И БАЗАЛЬНЫХ НИЖНЕЮРСКИХ ОТЛОЖЕНИЙ ЗАПАДНОЙ ЧАСТИ НАДЫМ-ТАЗОВСКОЙ СИНЕКЛИЗЫ
}

Насонов B.A., Самсонова Н.A. (

В приведенной работе обсуждаются некоторые вопросы, связанные с изучением строения и перспектив нефтегазоносности палеозойских отложений западной части Надым-Тазовской синеклизы в пределах Надымской геосинеклизы, проиллюстрированы примеры сейсмических волновых картин, используемых для решения задач сейсмогеологического моделирования на участке региональныг профилей в районе Ярудейского крупного вала.

В докладе будут приведены сведения о геологическом строении и перспективах нефтегазоносности палеозойских отложений и отложений зоны контакта палеозоя, полученные по новым сейсмическим и геологическим материалам Полярной Геофизической Экспедиции сп69/04-07 rг с использованием информации из отчетов о ранее проведенньх работах на площадях западной части Надым-Тазовской синеклизы, опубликованных материалов и литературных источников.

Комплексный анализ сейсмогеологического материала, по линиям региональных профилей XXV и XXVI, композитньх профилей, отдельньг профилей, некоторьт участков плошади на восточном склоне Ярудейского крупного вала позволяют предполагать с высокой степенью вероятности наличие благоприятньх условий для формирования структурно-стратиграфических,

структурнолитологических и более сложноэкранированных ловушек нефти и газа в палеозойских отложениях и в зоне контакта палеозоя и юры.

Во-первых, этому способствует огромный нефтегазогенерационный потенциал толщ, выполняющих древние депрессии. Анализ волновой картины по региональному профилю XXV, пересекающему площадь работ доказывает линзовидное строение Ярудейского орогенного прогиба, нижняя прослеживаемая граница которого контролируется OГ, условно проиндексированным нами как А5, ниже этой границы прослеживаются более слабые отражения, свидетельствующие о существенно большей глубине этой палеодепрессии.

Глубинный разрез по этому же профилю в районе западного и восточного бортов прогиба позволил уверенно выделить сейсмофации заполнения в палеозойском сейсмостратиграфическом комплекce.

Характерно резкое усиление энергии OB, контролирующих антиклинальные осложнения внутри прогиба и вдоль его бортов, что может быть индикатором газонасыщения проницаемых пластов, в которьг сформировались СЛ и ССЛ.

Подобная картина наблюдается по ряду композитныт профилей. Просдет и картопостроение в площадном варианте мгновенных амплитуд в интервале между ОГ $\mathrm{A}$ и фиктивным горизонтом A+500 мс позволили оконтурить аномалию, связываемую с возможным газонасышением палеозойских проницаемых пластов-коллекторов.
В волновой картине других профилей выделены структурно-сводовые ловушки в сейсмофациях заполнения палеопрогиба в палеозойском сейсмостратиграфическом комплекск (ССК). Наблюдаемы на отдельных временныг разрезах аномалии мгновенных амплитуд в интервалах залегания зоны контакта палеозой-юрских отложений при площадном картировании оконтуриваются в очень контрастные зоны типа АТЗ.

Для исследуемого района характерной является картина прекращения прослеживаемости $\mathrm{OB}$ по схеме прилегания к палеовыступам фундамента, наблюдаемая на уровне контакта палеозойских (ОГ А) и нижнеюрских $\left(\mathrm{Tю}_{13}\right)$ отложений.

Выводы: Обзор типов волновых картин, анализ геологического строения палеозойских отложений в рассматриваемом районе, сведений о нефтегазоносности пластов, полученных в результате испытаний пластов в пробуренных скважинах на ряде площадей северной части Западно-Сибирского нефтегазоносного бассейна ( к на площадях западной пасти Надьм-Тазовской геосинеклизы) позволяет выделить два наиболее характерных типа структурно-стратиграфических ловушек (внутрипалеозойские ССЛ и ловушки налегания зоны контакта PZMZ в пл.Ю11-13) и рассматривать территорию западной части Надым-Тазовской синеклизы как перспективную в отношении нефтегазоносности палеозойско-нижнеюрских глубоких горизонтов.

Авторы доклада выражают благодарность Заказчику работ Компании ООО «Тайликснефтегаз) за разрешение использовать сейсминеские и геологические материалы, полученные при выполнении комплексной интерпретации материалов по Аномальному лицензионному участку.

\section{ЛИТЕРАТУРA:}

1. Конторович А.Э., Нестеров И.И., Салманов Ф.К. и др. Геология нефти и газа Западной Сибири. М., Недра, 1975, 680 с.

2.Бочкарев В.С. Геологическое строение палсозойского и триасового комнлексов в Пуровском регионе и перспективы их нефтегазоносности Надым-Пур-Тазовского междуречья, Тюмень-ТаркоСале, 1995 , с. $179-206$.

3.Бочкарев В.С. Структурно-формационный анализ глубоких горизонтов нижнеюрско-палеозойских осадочных комплексов Заладной Сибири с целью выделения главньгх зон нефтегазонакопления и конщентрации поисковых работ. Отчет по договору 021, ЗапСибНИГ НИ, Тюмень, 1990.

4.Бочкарев В.С. Промежуточный отчет по теме $1-02$ «Создание геологических моделей строения палеозойского нефтегазоносного комплекса и разработка главных направлений подготовки и освоения его ресурсного потенциала в северньх раћ̆онах Западной Сибири» за 2003 год. Тюмень, 2003.

5. Насонов В.А., Самсонова Н.А. Отчет о результатах комплексной интерпретации по материалам сейсморазведки и бурения по Аномальной площдади. ЗАО НПЦ СибТЕО за 2007 г 